\title{
Effects of inoculation by arbuscular mycorrhizal fungi on the composition of the essential oil, plant growth, and lipoxygenase activity of Piper aduncum L.
}

Joyce Solange F. de Oliveira', Luciana P. Xavier', Alba Lins², Eloisa Helena A. Andrade², José Guilherme S. Maia ${ }^{3}$, Andréa H. de Mello ${ }^{4}$, William N. Setzer ${ }^{5}$, Alessandra R. Ramos ${ }^{6}$ and Joyce Kelly R. da Silva ${ }^{{ }^{*}(0)}$

\begin{abstract}
The aim of this study was to evaluate the changes in the production of secondary metabolites Piper aduncum seedlings were inoculated by spores of the arbuscular mycorrhizal fungi (AMF) Rhizophagus clarus and Claroideoglomus etunicatum. P. aduncum seedlings were inoculated by spores of $R$. clarus and C. etunicatum and then, development parameters, root colonization, lipoxygenase (LOX) activity, and essential oil (OE) chemical composition were monitored at 30,60 and 90 days' post-inoculation (dpi). The inoculation had influenced the plant height and root length at 30 and $90 \mathrm{dpi}$ and microscopic analysis of roots showed the presence of hyphae, arbuscules and vesicles in the inoculated plants. Phenylpropanoids and sesquiterpene hydrocarbons were the main compounds in the EO. In the leaves, the concentration of phenylpropanoids showed a decrease, mainly at $60 \mathrm{dpi}$, with increased sesquiterpene hydrocarbon production. The main compounds were dillapiole, myristicin, and germacrene D; the dillapiole concentration decreased in all treatments. LOX activity had an increase in the leaves and roots at $90 \mathrm{dpi}$. These results suggest that alterations in the secondary metabolites of $P$. aduncum can be induced by its mechanisms of resistance during AMF interaction.
\end{abstract}

Keywords: Arbuscular mycorrhizal fungi, Volatile compounds, Dillapiole, Lipoxygenase, Secondary metabolites

\section{Introduction}

Piperaceae have wide distributions in tropical and subtropical regions, and are known as a pantropical family with approximately 2700 species mainly of the genus Piper (The Plant List 2013). Piper aduncum L. is a bush native to tropical regions of the Americas, but it was introduced to Asia during the nineteenth century (Hartemink 2001; Yuncker 1972). In the Amazon region, it is commonly known as "pimenta-de-macaco", and used in popular medicine to treat intestinal apathy and stomach problems (Sousa et al. 2008). In addition, the P. aduncum essential oil (EO) has demonstrated several biological

\footnotetext{
*Correspondence: joycekellys@ufpa.br

${ }^{1}$ Programa de Pós-Graduação em Biotecnologia, Universidade Federal do Pará, Belém, Pará, Brazil

Full list of author information is available at the end of the article
}

properties, such as antifungal (Guerrini et al. 2009), antimicrobial (Kloucek et al. 2005), insecticidal (Misni et al. 2011), and larvicidal (Almeida et al. 2009) activities. These biological properties can be attributed to its main compound, dillapiole, a phenylpropanoid which presents in amounts of 31.5 to $91.1 \%$ (Maia et al. 1998).

The biosynthesis of secondary metabolites in medicinal and aromatic plants depends on genetic, physiological, and environmental factors (Freitas et al. 2004). Among these factors, the symbiotic association of plants by root colonization by arbuscular mycorrhizal fungi (AMF) can produce a difference in its biosynthesis of secondary metabolites (Carlsen et al. 2008). AMF belongs to the Glomeromycota phylum and the Acaulospora, Entrophospora, Gigaspora, Glomus, Sclerocystis and Scutellispora genera (Oehl et al. 2011). AMFs have shown associations 
with about $80 \%$ of ground plants in natural ecosystems and cultivated agroecosystems, varying the colonization level according to plant genotype (Bonfante and Genre 2010; Smith and Read 2008).

The plants colonized by AMFs are more tolerant to low availability of water in the soil, making more efficient use of the absorbed water. In addition, they improve the plant nutrition, development, and the content of the essential oils, due to changes in the biosynthesis of secondary metabolites (Al-karaki et al. 2004; Nell et al. 2010). Thus, the aim of this study was to evaluate the changes in the production of secondary metabolites during the association of $P$. aduncum with AMFs.

\section{Materials and methods}

\section{Plant material and cultivation}

P. aduncum was collected in Belém/PA, Brazil, and a voucher specimen was deposited under register MG 218522 in the Emílio Goeldi Museum herbarium, city of Belém, Pará, Brazil. Cuttings containing 1 to 2 nodes were propagated and conditioned in vermiculite expanded type B substrate (Urimamã Mineração Ltda, Santa Maria da Boa Vista, Brazil), and kept in a greenhouse under $70 \%$ shading. The commercial nutrient solution (Biofert Root) was applied to promote root development and reapplied after 15 days, and the cuttings were moistened daily. After 21 days, the roots had developed, and seedlings were transplanted into polypropylene bags of approximately $9 \mathrm{~cm}$ in diameter, on a commercial substrate containing a mixture of limestone, castor oil, bone meal, and expanded vermiculite type $B$.

\section{Multiplication of AMF spores and production of fungal inoculant}

AMF spores (Rhizophagus clarus and Claroideoglomus etunicatum) were obtained from rhizosphere soil samples from the southeast Pará State, Amazon region (Brazil). They were multiplied in a greenhouse in sterile sand, using Brachiaria brizantha as trap culture (Da Luz et al. 2016). The identification of species was realized by morphological comparison based in the International Culture Collection of (Vesicular) Arbuscular Mycorrhizal Fungi (INVAM 1992). Inoculates, with the proportion of $50 \%$ each fungal species, composed of a mixture of spores (density of 90 spores/g soil), hyphae, root fragments and sterile sand, were used during the inoculation. Holes with approximately $2 \mathrm{~cm}$ deep were opened and the $6 \mathrm{~g}$ of inoculum was surface-spread on the roots. Non-inoculated seedlings were used as the control group.

\section{Experimental design}

Experimental design was performed in completely randomized blocks. Each group was composed of 10 plants, which were labeled as control (non-inoculated) and AMF (inoculated by AMFs). Roots and leaves were collected at 30,60 and 90 days post inoculation (dpi) to monitor the mycorrhizal colonization, plant development, secondary metabolites, and LOX activity. All analyzes were performed in biological triplicates.

\section{Mycorrhizal colonization in $P$. aduncum roots}

For the visualization of mycorrhizal colonization, usual techniques in plant anatomy were employed (Kraus and Arduin 1997). Root fragments of approximately $1 \mathrm{~cm}$ were fixed during $24 \mathrm{~h}$ in glutaraldehyde $1 \%$ in $0.1 \mathrm{M}$ phosphate buffer, pH 7.2 (according to Karnovsky 1965, with modifications). Afterward, the samples were dehydrated with a series of butyl alcohol treatments and then encased in histological paraffin (Johansen 1940). Longitudinal sections $(12 \mu \mathrm{m}$ thick) were obtained using an automatic microtome (Leica ${ }^{\circledR}$ RM 2245, Nussloch, Germany), the sections were stained with safranine and astra blue (Gerlach 1969), and mounted in Entellan ${ }^{\circledR}$ synthetic resin (Merck, Darmstadt, Germany). Photomicrographs were obtained using in Cannon digital camera (model A65015), coupled to a Zeiss microscope (model 426126.)

\section{Plant development evaluation}

The developmental parameters evaluated were: plant height $(\mathrm{cm})$, number of leaves, plant basal stem $(\mathrm{mm})$, number of nodes, root length $(\mathrm{cm})$, and the fresh mass of leaves and roots $(\mathrm{g})$ for each plant per replicate. The fresh leaf biomass production was based in the total weight per plant and the fresh root biomass in the total weight of the roots per plant.

\section{Extraction and analysis of the essential oils}

The essential oil fractions from fresh leaves and roots $(2.0 \mathrm{~g})$ of $P$. aduncum were obtained by simultaneous distillation-extraction process using a Likens-Nickerson apparatus for $2 \mathrm{~h}$ and $n$-pentane $(3 \mathrm{~mL})$ as solvent. After extraction, an aliquot $(1.0 \mu \mathrm{L})$ of the organic phase was analyzed by gas chromatography. Qualitative analysis was carried out on a GC-MS (Shimadzu QP2010 plus instrument) under the following conditions: Rtx-5MS silica capillary column $(30 \mathrm{~m} \times 0.25 \mathrm{~mm} \times 0.25 \mathrm{~mm}$ film thickness); programmed temperature, $60-240{ }^{\circ} \mathrm{C}\left(3{ }^{\circ} \mathrm{C} /\right.$ min); injector temperature, $200{ }^{\circ} \mathrm{C}$; carrier gas, helium, adjusted to a linear velocity of $1.2 \mathrm{~mL} / \mathrm{min}$; injection type, splitless; split flow was adjusted to yield a 20:1 ratio; septum sweep was a constant $10 \mathrm{~mL} / \mathrm{min}$; EIMS, electron energy, $70 \mathrm{eV}$; temperature of the ion source and connection parts, $200{ }^{\circ} \mathrm{C}$. The retention index was calculated for all the volatile constituents using a homologous series of $n$-alkanes (C8-C32, Sigma-Aldrich) (Van Den Dool and Kratz 1966). The identification of compounds was 
performed by comparison of mass spectrum and retention index with data present in the libraries of Adams (2007) and NIST (2011).

\section{In vitro lipoxygenase (LOX) activity}

The substrate was prepared using $78 \mu \mathrm{L}$ of linoleic acid (Sigma-Aldrich, USA) and $90 \mu \mathrm{L}$ Tween 20 (SigmaAldrich), mixed with $10 \mathrm{~mL}$ of boiling water and a few drops of sodium hydroxide $(0.5 \mathrm{~N})$. The final volume was adjusted to $25 \mathrm{~mL}$, resulting in a sodium linoleate solution $(10 \mathrm{mM})$, which was stored at $-20{ }^{\circ} \mathrm{C}$. The LOX activity determination was carried out with $5 \mu \mathrm{L}$ of crude leaf extract and $50 \mu \mathrm{L}$ of sodium linoleate $(10 \mathrm{mM})$, mixed with $1950 \mu \mathrm{L}$ of sodium phosphate buffer $(50 \mathrm{mM})$ at $\mathrm{pH}$ 6.5. The absorbance at $234 \mathrm{~nm}$ for the reaction was monitored for $60 \mathrm{~s}$, using a UV-Visible spectrophotometer (Meireles et al. 2016).

\section{Statistical analysis}

All analyses were compared with the control group and the data were expressed as mean \pm standard deviation. Analyses of variance were conducted using GraphPad 6.0, followed Bonferroni tests whenever appropriate. Differences at $p<0.05$ were considered statistically significant.

\section{Results}

\section{Monitoring of colonization of $P$. aduncum roots by AMFs}

Histological sections of $P$. aduncum roots inoculated by AMF revealed evidence of the presence of mycorrhizal structures such as hyphae, arbuscules, and vesicles, which were absent in the control plants (Fig. 1a). At 30 days post inoculation (dpi), the cortex was colonized, and the presence of penetration apparatus composed by hyphopodium and hyphae (Fig. 1b) were observed. At 60 $\mathrm{dpi}$, an intense colonization was observed in the radicular cortex with presence of numerous intracellular hyphae (Fig. 1c). At $90 \mathrm{dpi}$, the colonization showed completely establishment due to the presence of several hyphae, arbuscles and vesicles (Fig. 1d-f). In addition, hyphatic anastomosis was also observed (Fig. 1g).

\section{Growth and development of inoculated and non-inoculated plants}

Inoculation effects were evaluated on development of $P$. aduncum plants and the values for each parameter were compared to the control group (Table 1). Statistical differences were not observed for parameters such as basal stem diameter and leaf numbers between inoculated plants and control group (Table 1). Inoculated plants displayed a gradual increase in plant height at 30 , and 90 dpi. The number of nodes in inoculated plants was higher at $90 \mathrm{dpi}$ but had not displayed statistical differences at 30, and $60 \mathrm{dpi}$. These results indicate that inoculation benefits were demonstrated after $90 \mathrm{dpi}$. The increase of fresh mass was observed only in the roots at $30 \mathrm{dpi}$.

\section{Variation of volatile compounds in the leaves and roots during the colonization by AMF}

The GC-MS analysis of volatiles of $P$. aduncum leaves and roots resulted in the identification of 65 and 79 compounds, respectively. The most representative compound classes identified were phenylpropanoids and sesquiterpene hydrocarbons such as dillapiole, myristicin, germacrene D and elemicin. In the leaves, the phenylpropanoid concentrations displayed a difference between inoculated and non-inoculated plants at $60 \mathrm{dpi}$ (Table 2). The main change was observed at $60 \mathrm{dpi}$, with a drastic decrease (87.94-52.58\%) in inoculated plants. In the roots, the most representative classes were phenylpropanoids $(\approx 95 \%)$ and sesquiterpene hydrocarbons $(\approx 12 \%)$. The production of phenylpropanoid showed an increase only at $30 \mathrm{dpi}$. However, concentrations of sesquiterpene hydrocarbons were lower in the inoculated plants at 30 and 60 dpi (Table 2).

At $30 \mathrm{dpi}$, quantitative and qualitative changes were observed in the leaves. Quantitatively, a decrease in the dillapiole content (93.74-86.11\%), and an increase of $\beta$-caryophyllene (0.27-2.62\%) and germacrene $\mathrm{D}$ production (1.28-2.78\%) was observed (Fig. 2). Qualitatively, the inoculated plants produced additional compounds not observed in the control plants, including $(E)$ - $\beta$-ocimene $(0.12 \%)$, terpinen-4-ol $(0.11 \%), \alpha$-copaene $(0.25 \%)$ and $n$-tetradecanol (1.54\%). At $60 \mathrm{dpi}$, there was an increase in the contents of $\beta$-caryophyllene $(2.16-5.58 \%)$, germacrene D (3.19-5.49\%), myristicin (2.71-4.70\%), and a greater decrease of dillapiole (83.57-44.73\%). Several monoterpenes and sesquiterpenes were produced only by inoculated plants, such as $(Z)-\beta$-ocimene $(1.10 \%)$, $(E)$ - $\beta$-ocimene $(2.84 \%)$, and $\beta$-selinene $(1.33 \%)$. At 90 dpi, only inoculated plants produced the monoterpene allo-ocimene (1.64\%), also displaying a decrease in the concentrations of dillapiole (48.66-39.36\%), myristicin (3.26-2.41\%), and apiol (2.54-1.83\%).

At $30 \mathrm{dpi}$, the hydrocarbon $n$-octane $(2.43 \%)$ was identified only in the roots of inoculated plants (Table 3 ). Quantitatively, the production of dillapiole displayed an increase (71.65-84.65\%) with a concomitant decrease in the concentrations of myristicin (17.45-10.52\%) and elemicin (2.23-0.28\%) (Fig. 2). In addition, there was a decrease in the amounts of $\alpha$-copaene (1.20-0.30\%), $\beta$-caryophyllene (1.50-0.53\%), and germacrene D $(1.16-0.37 \%)$.

At $60 \mathrm{dpi}$, important changes were observed: the inoculated plants produced 15 compounds which were absent in the control group. Dillapiole production showed a decrease $(61.12-54.15 \%)$ and a slight increase in the 

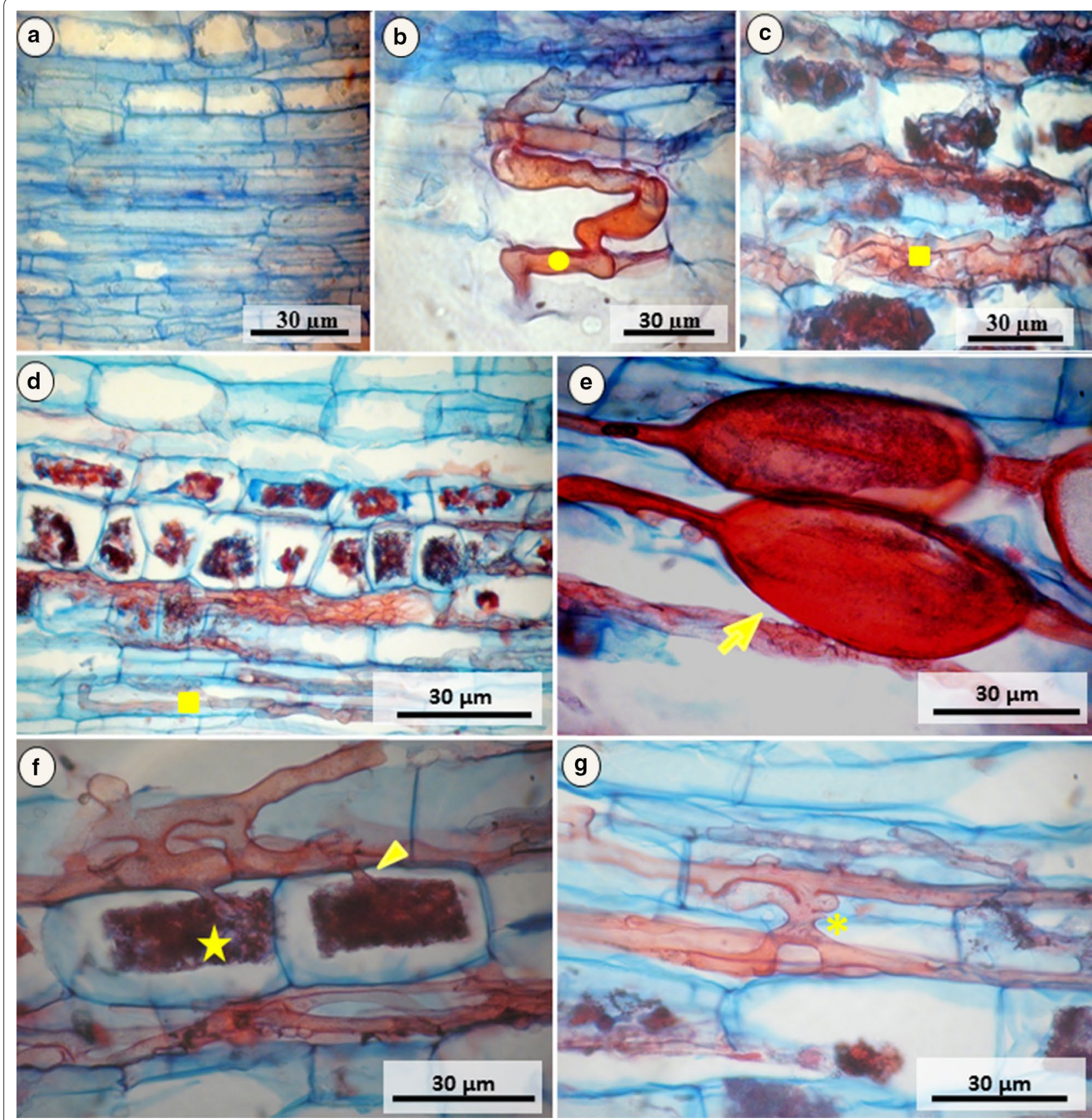

Fig. 1 Longitudinal Section of Piper aduncum root inoculated with mycorrhizal fungi arbuscular (AMFs). a Control sample; b Penetration of hyphae in epidermal cells with formation of hyphopodium in $30 \mathrm{dpi}$; c Intense colonization in $60 \mathrm{dpi}$; d Colonization in 90 dpi; e Formation of vesicles in 90 dpi; f Hyphae inter- and intracellularly and formation of arbuscules in 90 dpi; $\mathbf{g}$ Hepatic anastomosis in 90 dpi; (Filled circle) Hyphopodium; (Filled square) Intracellular hyphae; ( $\boldsymbol{\pi})$ Vesicles; ( $\star$ ) Arbuscules; (Filled triangle) Arbuscular trunks; ( $\boldsymbol{*}$ ) Hyphatic anastomosis

production of myristicin (18.38-19.93\%) and elemicin (2.22-3.13\%) was observed (Fig. 2). At 90 dpi, only inoculated plants produced detectible $(>0.1 \%)$ levels of the sesquiterpene trans-cadina-1(6),4-diene (1.34\%). The phenylpropanoids myristicin (19.25-18.47\%) and dillapiole (54.27-51.96\%) showed a decrease as well as the sesquiterpene hydrocarbons $\delta$-elemene $(0.40-0.29 \%)$ and $\alpha$-copaene $(1.91-1.63 \%)$. The minor compounds produced in the roots showed a behavior different than leaves, with a decrease of monoterpenes $(Z)$ - $\beta$-ocimene $(0.86-0.68 \%)$ and $(E)$ - $\beta$-ocimene $(0.77-0.57 \%)$ in inoculated plants (Table 3). 
Table 1 Developmental parameters of $P$. aduncum during inoculation by AMFs

\begin{tabular}{|c|c|c|c|c|c|c|c|c|}
\hline \multirow[t]{2}{*}{ dpi } & \multirow[t]{2}{*}{ Treatments } & \multicolumn{7}{|c|}{ Evaluation parameters ${ }^{a}$} \\
\hline & & Basal stem (mm) & Leaves & Node & Height (cm) & $\operatorname{Root}(\mathrm{cm})$ & Fresh weight (leaves) & Fresh weight (root) \\
\hline \multirow[t]{2}{*}{30} & Control & $3.9 \pm 0.0$ & $4.7 \pm 0.6$ & $4.3 \pm 0.6$ & $21.0 \pm 1.7$ & $37.7 \pm 1.2$ & $4.9 \pm 0.9$ & $4.3 \pm 0.7$ \\
\hline & AMF & $3.8 \pm 0.2$ & $5.3 \pm 0.6$ & $5.3 \pm 0.6$ & $30.5 \pm 2.2^{*}$ & $44.0 \pm 1.7$ & $6.9 \pm 1.1$ & $7.5 \pm 0.9^{*}$ \\
\hline \multirow[t]{2}{*}{60} & Control & $5.5 \pm 0.9$ & $7.3 \pm 0.6$ & $7.0 \pm 1.0$ & $37.7 \pm 2.5$ & $36.4 \pm 1.1$ & $2.2 \pm 0.8$ & $3.8 \pm 0.9$ \\
\hline & AMF & $6.3 \pm 0.4$ & $6.7 \pm 0.6$ & $6.7 \pm 0.6$ & $41.3 \pm 1.5$ & $30.1 \pm 7.0$ & $4.5 \pm 0.2$ & $5.2 \pm 1.2$ \\
\hline \multirow[t]{2}{*}{90} & Control & $6.1 \pm 0.9$ & $15.0 \pm 1.0$ & $16.0 \pm 0.8$ & $53.8 \pm 0.9$ & $53.3 \pm 0.5$ & $14.5 \pm 1.9$ & $7.8 \pm 0.8$ \\
\hline & AMF & $7.2 \pm 0.7$ & $16.3 \pm 2.1$ & $18.3 \pm 0.6^{*}$ & $61.1 \pm 4.3^{*}$ & $57.0 \pm 1.0$ & $17.2 \pm 1.5$ & $8.8 \pm 0.4$ \\
\hline
\end{tabular}

dpi: Days post inoculation; Control: P. aduncum non-inoculated with AMF; AMF: P. aduncum inoculated with AMF

* Statistical difference according to Bonferroni-test $(p<0.05)$

a Mean \pm standard deviation $(\mathrm{n}=3)$

\section{Evaluation of lipoxygenase activity in $P$. aduncum during AMF inoculation}

LOX activity was about 4 times greater in the leaves compared to the roots of $P$. aduncum. The leaves of inoculated plants showed an increase of LOX activity at 60 and $90 \mathrm{dpi}$ (Fig. 3a). However, in the roots its increase was observed only at 30 and $90 \mathrm{dpi}$ to inoculated plants (Fig. 3b).

\section{Discussion}

In the first stage of mycorrhizal colonization, the formation of the penetration apparatus (hyphopodium) occurred, presumably due to the recognition of signaling molecules of the plant by AMF, after the exchange of biochemical signals between fungus and host (Gianinazzi-Pearson and Brechenmacher 2004; Requena et al. 2002). After the formation of the appressorium in the epidermis and the intracellular extension of the hyphae, the AMF was established between the cell walls of the plant until reaching the cortex (Kiriachek et al. 2009). P. aduncum roots showed a typical Arumtype colonization, which consists of an extension of the intracellular hyphae at the beginning of colonization, followed by penetration into the cells of the root cortex, forming terminal arbuscles that bind the hyphae through arbuscular trunks (Fig. 1f) (Smith and Smith 1997). Arum-type colonization has also been observed in roots of 22 plant species including Piper nigrum, inoculated with AMF from the genus Acaulospora, Gigaspora, Glomus and Scutellospora (Muthukumar and Tamilselvi 2010).

The presence of mycorrhizal structures into radicular cells indicates the colonization and exchange of nutrients between host plants and AMF, mostly in arbuscules, which are considered the key in this process, and present a development cycle until degeneration. In addition, water is absorbed by the external mycelium and moves through the hyphae, which favors the apoplastic flow in the root system of the plant (Bárzan et al. 2012). The vesicles are globular or elliptical structures, which store lipids and glycogen, serving as a reserve organ for the fungus, and their formation can occur within or between the cells of the root cortex (Smith and Read 2008). These fungal structures were also observed in roots of plants of Poincianella pyramidalis and Cnidoscolus quercifolius that were inoculated by Acaulospora longula and C. etunicatum (Frosi et al. 2016).

The developmental parameters of inoculated plants showed significant variation only in the height of plants at 30 and 90 dpi and node number at 90 dpi. Our results are distinct in comparison with Piper longum plants inoculated with Glomus fasciculatum, Acaulospora foveata and Gigaspora margarita, which showed an increase in leaf number. However, there was a decrease in root development, mostly for plants inoculated with G. fasciculatum (Seema and Garampalli 2015). The height variation in $P$. aduncum plants was similar to that observed in basil (Ocimum basilicum) and rosemary (Rosmarinus officinalis) inoculated with G. clarum spores, which showed an increase of 45.49 and 25.93\%, respectively (Russomanno et al. 2008). AMF contributes to increasing photosynthesis rate, favoring plant growth (Tanaka and Fujita 1979). The increase in height, but not in the number of leaves, indicates a possible production of photoassimilates directed to the needs of the plant (Neumann et al. 2009). The AMF species Gigaspora margarita, Acaulospora longula and C. etunicatum were considered as promoters of growth and better biomass production in P. longum seedlings (Seema and Garampalli 2015).

The contribution of AMF to increases of nutrients and biomass can be important when nutrient availability in the soil is low, thereby promoting a higher efficiency through the benefits of photoassimilates produced in 
Table 2 Comparison of volatile components produced in inoculated and non-inoculated leaves of $P$. aduncum (Mean standard deviation)

\begin{tabular}{|c|c|c|c|c|c|c|c|c|}
\hline \multirow[t]{2}{*}{ Compound } & \multirow[t]{2}{*}{$\mathrm{RI}^{\text {calc }}$} & \multirow[t]{2}{*}{$\mathrm{RI}^{\text {lit }}$} & \multicolumn{2}{|l|}{$30 \mathrm{dpi}^{\mathrm{a}}$} & \multicolumn{2}{|l|}{$60 \mathrm{dpi}^{\mathrm{a}}$} & \multicolumn{2}{|l|}{$90 \mathrm{dpi}^{\mathrm{a}}$} \\
\hline & & & Control & AMF & Control & AMF & Control & AMF \\
\hline a-Thujene & 931 & 924 & & & & $0.33 \pm 0.47$ & $0.48 \pm 0.67$ & $0.63 \pm 0.35$ \\
\hline$\beta$-Pinene & 976 & 974 & & & & $0.21 \pm 0.30$ & $0.15 \pm 0.21$ & $0.22 \pm 0.23$ \\
\hline Sabinene & 977 & 969 & & & & $0.24 \pm 0.34$ & $0.79 \pm 0.53$ & $0.84 \pm 0.03$ \\
\hline a-Phellandrene & 996 & 1002 & & & & & $0.14 \pm 0.20$ & $0.18 \pm 0.01$ \\
\hline$\delta$-2-Carene & 1006 & 1001 & & & & & & $0.08 \pm 0.01$ \\
\hline$\delta$-3-Carene & 1015 & 1008 & & & & & $0.06 \pm 0.08$ & \\
\hline Limonene & 1028 & 1024 & & & & $0.32 \pm 0.33$ & $0.21 \pm 0.29$ & $0.33 \pm 0.29$ \\
\hline (Z)- $\beta$-Ocimene & 1032 & 1032 & & $0.02 \pm 0.00$ & & $1.10 \pm 0.21$ & $2.07 \pm 0.33$ & $2.59 \pm 0.02$ \\
\hline (E)- $\beta$-Ocimene & 1043 & 1044 & & $0.12 \pm 0.00$ & & $2.84 \pm 0.01$ & $6.58 \pm 2.03$ & $6.76 \pm 0.41$ \\
\hline$\gamma$-Terpinene & 1046 & 1054 & & & & $0.27 \pm 0.38$ & $0.21 \pm 0.05$ & $0.41 \pm 0.21$ \\
\hline Terpinolene & 1084 & 1086 & & & & & & $0.34 \pm 0.00$ \\
\hline allo-Ocimene & 1126 & 1128 & & & & $0.62 \pm 0.03$ & & $1.64 \pm 0.16$ \\
\hline Terpinen-4-ol & 1179 & 1174 & & $0.11 \pm 0.24$ & & $0.36 \pm 0.30$ & $0.32 \pm 0.24$ & $0.56 \pm 0.27$ \\
\hline Piperitone & 1246 & 1249 & $0.04 \pm 0.05$ & $0.43 \pm 0.92$ & $0.16 \pm 0.23$ & $1.40 \pm 1.00$ & $1.12 \pm 0.75$ & $1.38 \pm 1.23$ \\
\hline a-Terpinyl formate & 1252 & 1306 & & & & & & $0.41 \pm 0.07$ \\
\hline Safrole & 1282 & 1285 & $0.01 \pm 0.01$ & & $0.04 \pm 0.01$ & $0.19 \pm 0.27$ & $0.04 \pm 0.06$ & \\
\hline$\delta$-Elemene & 1324 & 1335 & $0.08 \pm 0.06$ & $0.28 \pm 0.28$ & $0.54 \pm 0.07$ & $1.66 \pm 0.08$ & $2.33 \pm 0.49$ & $2.38 \pm 1.07$ \\
\hline a-Cubebene & 1344 & 1345 & & & & $0.05 \pm 0.01$ & & $0.04 \pm 0.04$ \\
\hline a-Ylangene & 1366 & 1373 & & $0.04 \pm 0.05$ & $0.05 \pm 0.06$ & $0.59 \pm 0.13$ & $0.38 \pm 0.06$ & $0.54 \pm 0.17$ \\
\hline a-Copaene & 1368 & 1374 & & $0.25 \pm 0.28$ & $0.17 \pm 0.19$ & $1.13 \pm 0.27$ & $0.40 \pm 0.57$ & $0.99 \pm 0.01$ \\
\hline$\beta$-Elemene & 1382 & 1389 & $0.14 \pm 0.08$ & $0.35 \pm 0.16$ & $0.73 \pm 0.01$ & $1.92 \pm 0.36$ & $1.71 \pm 0.04$ & $2.06 \pm 0.59$ \\
\hline n-Tetradecane & 1399 & 1400 & & & & $0.05 \pm 0.01$ & & $0.02 \pm 0.01$ \\
\hline$\beta$-Caryophyllene & 1412 & 1417 & $0.27 \pm 0.05$ & $2.62 \pm 1.03$ & $2.16 \pm 0.95$ & $5.58 \pm 0.76$ & $5.00 \pm 0.18$ & $4.84 \pm 0.54$ \\
\hline$\gamma$-Elemene & 1422 & 1434 & $0.23 \pm 0.16$ & $0.50 \pm 0.24$ & $0.45 \pm 0.63$ & $2.18 \pm 0.58$ & $2.07 \pm 0.08$ & $2.23 \pm 0.64$ \\
\hline$\beta$-Copaene & 1430 & 1430 & & & $0.42 \pm 0.59$ & $0.05 \pm 0.01$ & & $0.03 \pm 0.04$ \\
\hline Aromadendrene & 1435 & 1439 & & & & $0.13 \pm 0.08$ & $0.05 \pm 0.01$ & $0.10 \pm 0.03$ \\
\hline 6,9-Guaiadiene & 1438 & 1442 & & & & $0.11 \pm 0.03$ & $0.07 \pm 0.01$ & $0.11 \pm 0.05$ \\
\hline Isogermacrene D & 1441 & 1445 & & $0.01 \pm 0.03$ & $0.07 \pm 0.00$ & $0.35 \pm 0.06$ & $0.29 \pm 0.01$ & $0.40 \pm 0.13$ \\
\hline a-Humulene & 1452 & 1452 & $0.05 \pm 0.07$ & $0.62 \pm 0.47$ & $0.72 \pm 0.31$ & $2.38 \pm 0.11$ & $1.50 \pm 0.18$ & $1.73 \pm 0.24$ \\
\hline allo-Aromadendrene & 1456 & 1458 & & $0.01 \pm 0.03$ & & $0.29 \pm 0.11$ & $0.19 \pm 0.07$ & $0.24 \pm 0.01$ \\
\hline Dauca-5,8-diene & 1469 & 1471 & & $0.02 \pm 0.04$ & & $0.07 \pm 0.01$ & & $0.06 \pm 0.04$ \\
\hline Y-Muurolene & 1472 & 1478 & & & & $0.26 \pm 0.04$ & $0.13 \pm 0.01$ & $0.17 \pm 0.12$ \\
\hline Germacrene D & 1474 & 1484 & $1.28 \pm 0.78$ & $2.78 \pm 0.94$ & $3.19 \pm 0.08$ & $5.49 \pm 1.32$ & $6.50 \pm 0.45$ & $3.84 \pm 0.73$ \\
\hline$\beta$-Selinene & 1485 & 1489 & & $0.02 \pm 0.04$ & & $1.33 \pm 1.34$ & $0.07 \pm 0.10$ & $0.20 \pm 0.06$ \\
\hline a-Selinene & 1485 & 1498 & & & $0.02 \pm 0.02$ & & & \\
\hline Viridiflorene & 1488 & 1496 & & & & $0.17 \pm 0.02$ & $0.14 \pm 0.09$ & $0.19 \pm 0.16$ \\
\hline Bicyclogermacrene & 1492 & 1500 & $0.23 \pm 0.18$ & $0.36 \pm 0.40$ & $0.70 \pm 0.04$ & $2.15 \pm 0.34$ & $2.56 \pm 0.59$ & $2.74 \pm 0.69$ \\
\hline a-Muurolene & 1495 & 1500 & & $0.06 \pm 0.08$ & $0.14 \pm 0.00$ & $0.59 \pm 0.11$ & $0.24 \pm 0.33$ & $0.61 \pm 0.21$ \\
\hline n-Pentadecane & 1496 & 1500 & $0.78 \pm 0.29$ & $2.28 \pm 0.46$ & $1.66 \pm 1.07$ & $3.77 \pm 0.95$ & $2.48 \pm 0.23$ & \\
\hline$(E, E)$-a-Farnesene & 1502 & 1505 & & $0.05 \pm 0.11$ & $0.07 \pm 0.04$ & $0.50 \pm 0.18$ & $0.17 \pm 0.07$ & $0.19 \pm 0.01$ \\
\hline$\gamma$-Cadinene & 1509 & 1513 & $0.01 \pm 0.01$ & $0.02 \pm 0.04$ & $0.06 \pm 0.04$ & $0.32 \pm 0.06$ & $0.16 \pm 0.02$ & $0.54 \pm 0.08$ \\
\hline$\delta$-Cadinene & 1514 & 1522 & $0.07 \pm 0.03$ & $0.31 \pm 0.21$ & $0.19 \pm 0.02$ & $0.85 \pm 0.05$ & $0.53 \pm 0.14$ & $0.57 \pm 0.42$ \\
\hline Myristicin & 1517 & 1517 & $1.53 \pm 0.41$ & $0.61 \pm 0.60$ & $2.71 \pm 1.11$ & $4.70 \pm 0.11$ & $3.26 \pm 0.88$ & $2.41 \pm 2.32$ \\
\hline 7-epi-a-Selinene & 1526 & 1520 & & & & & & $0.01 \pm 0.01$ \\
\hline trans-Cadina-1.4-diene & 1529 & 1533 & & & & $0.11 \pm 0.02$ & $0.04 \pm 0.00$ & $0.05 \pm 0.04$ \\
\hline a-Cadinene & 1533 & 1537 & & & & $0.06 \pm 0.01$ & & $0.06 \pm 0.02$ \\
\hline a-Calacorene & 1538 & 1544 & & $0.01 \pm 0.03$ & & $0.22 \pm 0.13$ & $0.05 \pm 0.06$ & $0.11 \pm 0.06$ \\
\hline
\end{tabular}


Table 2 (continued)

\begin{tabular}{|c|c|c|c|c|c|c|c|c|}
\hline \multirow[t]{2}{*}{ Compound } & \multirow[t]{2}{*}{$\mathrm{R}^{\text {calc }}$} & \multirow[t]{2}{*}{$\mathrm{RI}^{\text {lit }}$} & \multicolumn{2}{|l|}{$30 \mathrm{dpi}^{\mathrm{a}}$} & \multicolumn{2}{|l|}{$60 \mathrm{dpi}^{\mathrm{a}}$} & \multicolumn{2}{|l|}{$90 \mathrm{dpi}^{\mathrm{a}}$} \\
\hline & & & Control & AMF & Control & AMF & Control & AMF \\
\hline Elemol & 1542 & 1548 & & & & & & $0.07 \pm 0.14$ \\
\hline Germacrene B & 1554 & 1559 & & & & $0.07 \pm 0.01$ & $0.05 \pm 0.01$ & $0.08 \pm 0.08$ \\
\hline (E)-Nerolidol & 1559 & 1561 & & & $0.08 \pm 0.11$ & $0.41 \pm 0.10$ & $0.17 \pm 0.01$ & $0.34 \pm 0.08$ \\
\hline Palustrol & 1566 & 1567 & & & & $0.04 \pm 0.05$ & $0.02 \pm 0.03$ & $0.06 \pm 0.04$ \\
\hline Spathulenol & 1573 & 1577 & & & $0.12 \pm 0.16$ & $0.40 \pm 0.57$ & & $0.23 \pm 0.00$ \\
\hline Caryophyllene oxide & 1578 & 1582 & $0.065 \pm 0.09$ & $0.05 \pm 0.10$ & $0.12 \pm 0.06$ & $0.79 \pm 0.48$ & $0.27 \pm 0.19$ & $0.30 \pm 0.42$ \\
\hline Globulol & 1582 & 1590 & & & & $0.09 \pm 0.05$ & & $0.11 \pm 0.04$ \\
\hline Viridiflorol & 1591 & 1592 & & & & $0.23 \pm 0.12$ & $0.50 \pm 0.59$ & $0.42 \pm 0.46$ \\
\hline Humulene epoxide II & 1606 & 1608 & $0.04 \pm 0.06$ & $0.04 \pm 0.09$ & $0.01 \pm 0.01$ & $0.08 \pm 0.11$ & $0.03 \pm 0.04$ & $0.20 \pm 0.21$ \\
\hline 1,10-di-epi-Cubenol & 1609 & 1618 & & & & & & $0.04 \pm 0.03$ \\
\hline Dillapiole & 1623 & 1620 & $93.74 \pm 0.01$ & $86.11 \pm 9.45$ & $83.57 \pm 3.39$ & $44.73 \pm 1.67$ & $48.66 \pm 2.11$ & $39.36 \pm 6.58$ \\
\hline epi-a-Muurolol & 1644 & 1640 & & & $0.02 \pm 0.02$ & & $0.16 \pm 0.11$ & $0.58 \pm 0.30$ \\
\hline a-Muurolol & 1646 & 1644 & & & & $0.25 \pm 0.35$ & $0.02 \pm 0.03$ & $0.07 \pm 0.05$ \\
\hline a-Cadinol & 1654 & 1652 & & & $0.09 \pm 0.13$ & & $0.36 \pm 0.08$ & $0.44 \pm 0.52$ \\
\hline Apiole & 1669 & 1677 & $0.42 \pm 0.26$ & $0.11 \pm 0.06$ & $1.24 \pm 0.28$ & $2.01 \pm 2.84$ & $2.54 \pm 0.92$ & $1.83 \pm 1.43$ \\
\hline n-Tetradecanol & 1676 & 1671 & & $1.54 \pm 3.23$ & $0.02 \pm 0.02$ & $0.01 \pm 0.13$ & $0.10 \pm 0.01$ & $0.12 \pm 0.01$ \\
\hline Monoterpene hydrocarbons & & & & $0.14 \pm 0.00$ & & $5.93 \pm 2.07$ & $10.69 \pm 4.39$ & $14.02 \pm 1.72$ \\
\hline Oxygenated monoterpenes & & & $0.04 \pm 0.05$ & $0.54 \pm 1.16$ & $0.16 \pm 0.23$ & $1.76 \pm 1.30$ & $1.44 \pm 0.99$ & $2.35 \pm 1.57$ \\
\hline Sesquiterpene hydrocarbons & & & $3.14 \pm 1.71$ & $10.59 \pm 4.29$ & $11.34 \pm 4.12$ & $32.49 \pm 7.20^{*}$ & $27.17 \pm 3.88$ & $25.22 \pm 6.38$ \\
\hline Oxygenated sesquiterpenes & & & $0.11 \pm 0.15$ & $0.09 \pm 0.19$ & $0.44 \pm 0.49$ & $2.29 \pm 1.83$ & $1.53 \pm 1.08$ & $2.86 \pm 2.29$ \\
\hline Phenylpropanoids & & & $95.86 \pm 0.92$ & $86.83 \pm 10.11$ & $87.94 \pm 4.85$ & $52.58 \pm 5.02^{*}$ & $55.16 \pm 4.03$ & $44.26 \pm 10.57$ \\
\hline Others & & & & $1.54 \pm 3.23$ & $0.02 \pm 0.02$ & $0.01 \pm 0.13$ & $0.10 \pm 0.01$ & $0.12 \pm 0.01$ \\
\hline Total & & & $99.15 \pm 2.83$ & $99.73 \pm 18.98$ & $99.90 \pm 9.71$ & $95.06 \pm 17.55$ & $96.09 \pm 14.38$ & $88.83 \pm 22.54$ \\
\hline
\end{tabular}

dpi: Days post inoculation; Control: P. aduncum non-inoculated with AMF; AMF: P. aduncum inoculated with AMF; RI cal: Retention index calculated; Rl lit: Retention Index of Library

* Statistical difference according to Bonferroni test $(p<0.05)$

a Mean \pm standard deviation $(n=3)$

the host plant (Neumann et al. 2009; Smith and Smith 1997; Xie et al. 2014). In this case, this hypothesis can explain the lower variation in the biomass production in $P$. aduncum because we have used a soil rich in nutrients. The production of substances by inoculated plants may be related to defense mechanisms during the AMF colonization, which led to increased expression of defense-related genes and production of volatile compounds such as alcohols, ethers, and aldehydes in their leaves (Quaglia et al. 2012). These metabolites are produced by enzymes, including the lipoxygenases, and are considered compounds involved in signaling and defense (Liavonchanka and Feussner 2006).

Several chemical compounds are involved in the plant interaction, including low-molecular-weight and monoterpenes such as myrcene and mixtures of ocimene isomers made up of $(E)$ - $\beta$-ocimene, $(Z)$ $\beta$-ocimene and allo-ocimene (Godard et al. 2008). Among the minor compounds, $(E)-\beta$-ocimene and
(Z)- $\beta$-ocimene showed a gradual increase during inoculation by AMF in the leaves and a decrease in the roots. These compounds are emitted by plants to response to herbivore attack and changes in abiotic factors (Gouinguené and Turlings 2002).

Our observations showed a correlation with LOX activity in the leaves of inoculated plants; the increase of LOX activity indicating a possible defense mechanism of plant (Baysal and Demirdoven 2007). The regulation of the by-product of the LOX pathway, jasmonic acid, can promote changes in the colonization level by AMF in plants (Gutjahr et al. 2015). The activation of the LOX pathway enhances important functions in the primary and secondary metabolism in the plants (Morcillo et al. 2012).

LOX is involved in the production of volatile compounds in leaves and roots such as alcohols, ethers, and aldehydes, which are considered both signaling and defense compounds (Liavonchanka and Feussner 2006). 

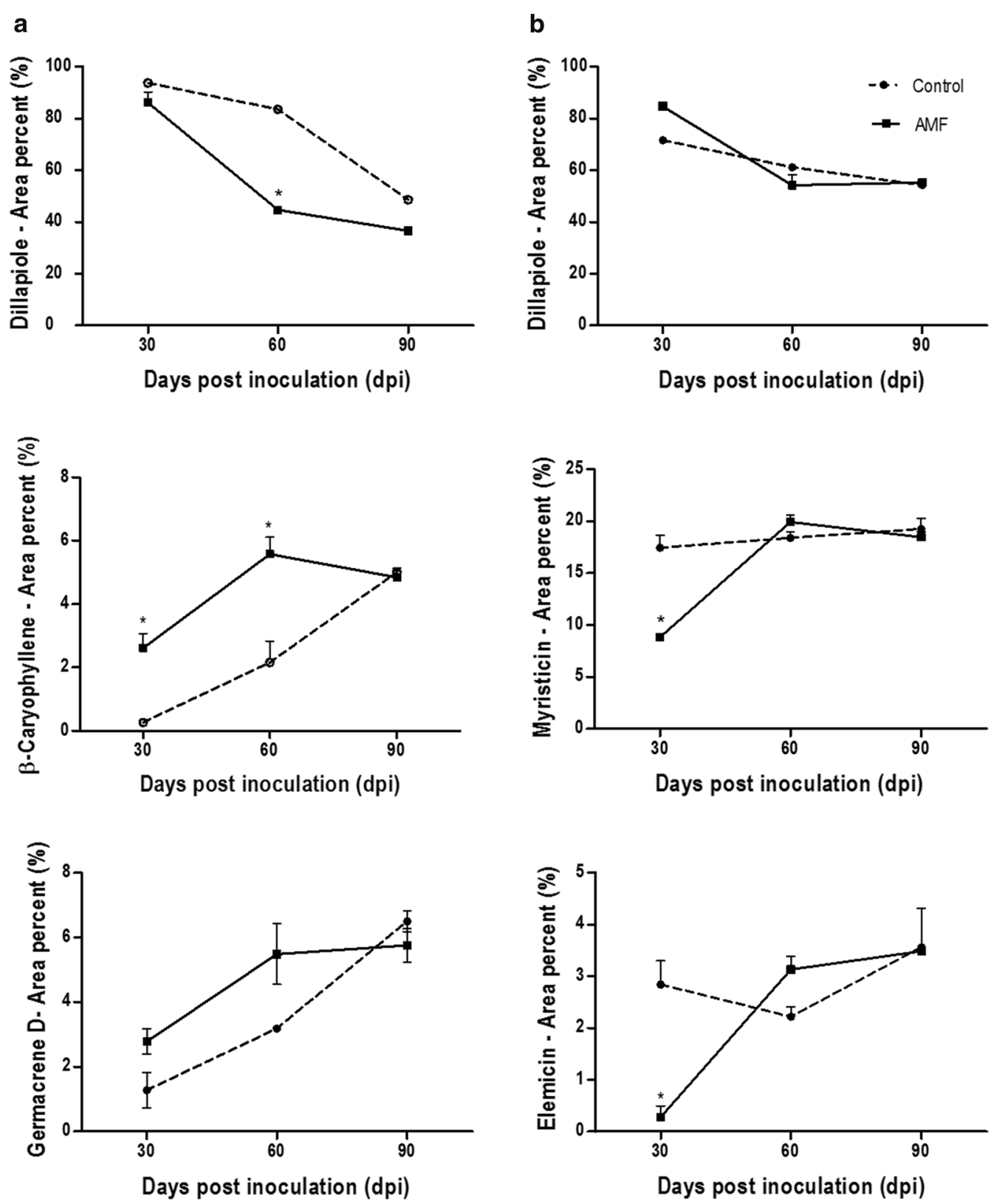

Fig. 2 Major compounds produced by P. aduncum during inoculation with arbuscular mycorrhizal fungi (AMFs). a Leaves; b Roots. *Statistical difference according to Bonferroni test $(p<0.05)$

After biotic and abiotic stress, LOX activity is increased, and it depends mostly on inducing agents as well as the plant genotype and physiologic conditions (Silva et al. 2004). The activation of LOX activity was induced by inoculation in the roots of Rhizophagus irregulars in bean plants (Phaseolus vulgaris L.) (Mora-Romero et al. 2015). At $21 \mathrm{dpi}$, LOX activity was increased about 50\% in P. divaricatum seedlings infected by Fusarium solani f. sp. piperis (Meireles et al. 2016).

$P$. aduncum presents many biological activities reported in the literature, which are attributed to the phenylpropanoid dillapiole (Bernard et al. 1995; Almeida et al. 2009; Souto et al. 2012). Alternatives to increase the production of dillapiole were investigated 
Table 3 Comparison of volatile components produced in inoculated and non-inoculated roots of $P$. aduncum (Mean standard deviation)

\begin{tabular}{|c|c|c|c|c|c|c|c|c|}
\hline \multirow[t]{2}{*}{ Compound } & \multirow[t]{2}{*}{$\mathrm{RI}^{\text {calc }}$} & \multirow[t]{2}{*}{$\mathrm{RI}^{\text {lit }}$} & \multicolumn{2}{|l|}{$30 \mathrm{dpi}^{\mathrm{a}}$} & \multicolumn{2}{|l|}{$60 \mathrm{dpi}^{\mathrm{a}}$} & \multicolumn{2}{|l|}{$90 \mathrm{dpi}^{\mathrm{a}}$} \\
\hline & & & Control & AMF & Control & AMF & Control & AMF \\
\hline n-Octane & 782 & 800 & & $2.43 \pm 1.18$ & & $0.10 \pm 0.10$ & $0.03 \pm 0.04$ & $0.14 \pm 0.04$ \\
\hline a-Thujene & 918 & 924 & & & $0.13 \pm 0.23$ & $0.46 \pm 0.14$ & $0.27 \pm 0.37$ & $0.33 \pm 0.10$ \\
\hline Camphene & 934 & 946 & $0.39 \pm 0.42$ & $0.07 \pm 0.13$ & $1.06 \pm 0.94$ & $1.86 \pm 0.45$ & $2.77 \pm 0.40$ & $1.68 \pm 0.34$ \\
\hline Sabinene & 963 & 969 & & & $0.05 \pm 0.08$ & $0.25 \pm 0.06$ & $0.16 \pm 0.23$ & $0.18 \pm 0.31$ \\
\hline Myrcene & 973 & 988 & & $0.02 \pm 0.03$ & & $0.16 \pm 0.14$ & & \\
\hline$\beta$-Pinene & 974 & 974 & & & & $0.07 \pm 0.13$ & $0.17 \pm 0.23$ & $0.30 \pm 0.03$ \\
\hline$\delta$-3-Carene & 998 & 1008 & $0.25 \pm 0.24$ & & $0.71 \pm 1.00$ & $1.77 \pm 0.46$ & $1.20 \pm 0.23$ & $0.82 \pm 0.54$ \\
\hline p-Cymene & 1013 & 1020 & & & & & & \\
\hline Limonene & 1018 & 1024 & & & $0.06 \pm 0.10$ & $0.22 \pm 0.15$ & $0.16 \pm 0.03$ & $0.30 \pm 0.23$ \\
\hline (Z)-B-Ocimene & 1033 & 1032 & $0.05 \pm 0.09$ & & $0.26 \pm 0.29$ & $0.58 \pm 0.06$ & $0.86 \pm 0.30$ & $0.68 \pm 0.19$ \\
\hline$(E)$ - $\beta$-Ocimene & 1043 & 1044 & $0.05 \pm 0.09$ & & $0.08 \pm 0.14$ & $0.34 \pm 0.06$ & $0.77 \pm 0.21$ & $0.57 \pm 0.24$ \\
\hline p-Mentha-2,4(8)-diene & 1074 & 1085 & & & & $0.04 \pm 0.04$ & & $0.05 \pm 0.04$ \\
\hline Linalool & 1090 & 1095 & & & & & & $0.07 \pm 0.06$ \\
\hline allo-Ocimene & 1119 & 1128 & & & & $0.09 \pm 0.01$ & $0.09 \pm 0.13$ & $0.79 \pm 1.32$ \\
\hline Camphor & 1138 & 1141 & $0.49 \pm 0.30$ & $0.10 \pm 0.10$ & $0.43 \pm 0.52$ & $1.28 \pm 0.66$ & $1.34 \pm 1.89$ & $0.11 \pm 0.03$ \\
\hline Camphene hydrate & 1147 & 1145 & & & $0.01 \pm 0.02$ & $0.04 \pm 0.04$ & $0.06 \pm 0.08$ & $0.09 \pm 0.02$ \\
\hline Isoborneol & 1147 & 1155 & $0.12 \pm 0.21$ & & $0.15 \pm 0.26$ & $0.62 \pm 0.29$ & $0.43 \pm 0.60$ & $0.39 \pm 0.13$ \\
\hline Borneol & 1156 & 1165 & & & $0.06 \pm 0.11$ & $0.06 \pm 0.05$ & $0.06 \pm 0.08$ & $0.04 \pm 0.04$ \\
\hline Citral & 1170 & 1174 & & & & & $0.04 \pm 0.06$ & $0.02 \pm 0.03$ \\
\hline Terpinen-4-ol & 1172 & 1174 & & & & & & $0.04 \pm 0.03$ \\
\hline a-Terpineol & 1187 & 1186 & $0.02 \pm 0.03$ & & $0.04 \pm 0.08$ & $0.13 \pm 0.04$ & $0.14 \pm 0.00$ & $0.16 \pm 0.02$ \\
\hline Piperitone & 1246 & 1249 & & & $0.06 \pm 0.10$ & $0.14 \pm 0.09$ & $0.04 \pm 0.06$ & $0.08 \pm 0.14$ \\
\hline Safrole & 1282 & 1285 & $0.05 \pm 0.04$ & & $0.06 \pm 0.05$ & $0.10 \pm 0.12$ & $0.07 \pm 0.01$ & $0.22 \pm 0.15$ \\
\hline$\delta$-Elemene & 1333 & 1335 & $0.11 \pm 0.04$ & $0.13 \pm 0.16$ & $0.52 \pm 0.26$ & $0.36 \pm 0.25$ & $0.40 \pm 0.23$ & $0.29 \pm 0.04$ \\
\hline a-Cubebene & 1342 & 1345 & & & $0.04 \pm 0.03$ & $0.06 \pm 0.07$ & $0.03 \pm 0.04$ & $0.02 \pm 0.03$ \\
\hline Cyclosativene & 1365 & 1369 & $0.17 \pm 0.14$ & & $0.42 \pm 0.10$ & $0.28 \pm 0.17$ & $0.34 \pm 0.03$ & $0.32 \pm 0.03$ \\
\hline a-Copaene & 1372 & 1374 & $1.20 \pm 0.51$ & $0.30 \pm 0.12$ & $2.35 \pm 0.32$ & $1.34 \pm 0.62$ & $1.91 \pm 0.22$ & $1.63 \pm 0.24$ \\
\hline$\beta$-Cubebene & 1385 & 1387 & & & $0.12 \pm 0.11$ & & $0.27 \pm 0.12$ & \\
\hline$\beta$-Elemene & 1386 & 1389 & $0.26 \pm 0.19$ & $0.02 \pm 0.03$ & $0.59 \pm 0.18$ & $0.65 \pm 0.41$ & $0.34 \pm 0.18$ & $0.58 \pm 0.08$ \\
\hline cis-a-Bergamotene & 1411 & 1411 & & & $0.01 \pm 0.01$ & & & \\
\hline$\beta$-Caryophyllene & 1416 & 1417 & $1.50 \pm 0.39$ & $0.53 \pm 0.16$ & $3.00 \pm 0.09$ & $2.35 \pm 1.01$ & $1.93 \pm 0.27$ & $2.03 \pm 0.08$ \\
\hline$\beta$-Copaene & 1427 & 1430 & $0.22 \pm 0.23$ & $0.08 \pm 0.08$ & $0.99 \pm 0.08$ & $0.70 \pm 0.36$ & $0.60 \pm 0.16$ & $0.64 \pm 0.05$ \\
\hline Y-Muurolene & 1428 & 1478 & $0.21 \pm 0.36$ & & & & & \\
\hline trans-a-Bergamotene & 1430 & 1432 & $0.02 \pm 0.03$ & & $0.08 \pm 0.04$ & $0.07 \pm 0.08$ & $0.03 \pm 0.04$ & $0.05 \pm 0.04$ \\
\hline Aromadendrene & 1435 & 1439 & & & $0.03 \pm 0.05$ & $0.03 \pm 0.05$ & & \\
\hline cis-Muurola-3,5-diene & 1442 & 1448 & $0.02 \pm 0.03$ & & $0.04 \pm 0.06$ & & & \\
\hline 6,9-Guaiadiene & 1443 & 1442 & & & & $0.16 \pm 0.10$ & $0.13 \pm 0.09$ & $0.14 \pm 0.02$ \\
\hline trans-Muurola-3,5-diene & 1445 & 1451 & $0.02 \pm 0.03$ & & $0.03 \pm 0.03$ & $0.02 \pm 0.03$ & & \\
\hline allo-Aromadendrene & 1448 & 1458 & & & & & $0.05 \pm 0.07$ & $0.06 \pm 0.01$ \\
\hline a-Humulene & 1452 & 1452 & $0.40 \pm 0.21$ & $0.15 \pm 0.08$ & $0.90 \pm 0.38$ & $0.83 \pm 0.50$ & $0.69 \pm 0.22$ & $0.72 \pm 0.04$ \\
\hline (E)- $\beta$-Farnesene & 1452 & 1454 & & & $0.14 \pm 0.24$ & & & \\
\hline$\beta$-Santalene & 1456 & 1457 & $0.06 \pm 0.06$ & & $0.17 \pm 0.09$ & $0.18 \pm 0.11$ & $0.11 \pm 0.04$ & $0.13 \pm 0.01$ \\
\hline trans-Cadina-1(6),4-diene & 1469 & 1475 & & & $0.02 \pm 0.04$ & $0.06 \pm 0.05$ & & $1.34 \pm 1.68$ \\
\hline a-Neocallitropsene & 1472 & 1474 & & & & & $0.08 \pm 0.01$ & $0.03 \pm 0.05$ \\
\hline$\gamma$-Curcumene & 1476 & 1481 & & & $0.68 \pm 1.12$ & $0.05 \pm 0.05$ & & \\
\hline Germacrene D & 1477 & 1484 & $1.16 \pm 0.58$ & $0.37 \pm 0.16$ & $1.39 \pm 1.23$ & $1.60 \pm 0.67$ & $1.59 \pm 0.48$ & $1.64 \pm 0.12$ \\
\hline$\beta$-Selinene & 1486 & 1489 & & & & $0.05 \pm 0.05$ & & \\
\hline
\end{tabular}


Table 3 (continued)

\begin{tabular}{|c|c|c|c|c|c|c|c|c|}
\hline \multirow[t]{2}{*}{ Compound } & \multirow[t]{2}{*}{$\mathrm{RI}^{\text {calc }}$} & \multirow[t]{2}{*}{$\mathrm{RI}^{\text {lit }}$} & \multicolumn{2}{|l|}{$30 \mathrm{dpi}^{\mathrm{a}}$} & \multicolumn{2}{|l|}{$60 \mathrm{dpi}^{\mathrm{a}}$} & \multicolumn{2}{|l|}{$90 \mathrm{dpi}^{\mathrm{a}}$} \\
\hline & & & Control & AMF & Control & AMF & Control & AMF \\
\hline Y-Muurolene & 1488 & 1478 & & & $0.03 \pm 0.05$ & & & \\
\hline trans-Muurola-4(14),5-diene & 1489 & 1493 & & & $0.05 \pm 0.08$ & $0.11 \pm 0.06$ & & $0.05 \pm 0.04$ \\
\hline a-Selinene & 1492 & 1498 & $0.03 \pm 0.05$ & & $0.06 \pm 0.10$ & & & \\
\hline Bicyclogermacrene & 1492 & 1500 & $0.04 \pm 0.06$ & & $0.19 \pm 0.22$ & $0.42 \pm 0.27$ & $0.22 \pm 0.13$ & $0.25 \pm 0.02$ \\
\hline a-Muurolene & 1495 & 1500 & $0.10 \pm 0.09$ & & $0.29 \pm 0.07$ & $0.26 \pm 0.13$ & $0.20 \pm 0.04$ & $0.23 \pm 0.03$ \\
\hline Pentadecane & 1499 & 1500 & $0.21 \pm 0.09$ & $0.15 \pm 0.12$ & $0.41 \pm 0.07$ & $0.23 \pm 0.10$ & $0.19 \pm 0.02$ & $0.27 \pm 0.06$ \\
\hline$\beta$-Bisabolene & 1505 & 1505 & $0.02 \pm 0.03$ & & $0.08 \pm 0.07$ & $0.08 \pm 0.09$ & $0.07 \pm 0.02$ & $0.13 \pm 0.06$ \\
\hline$\beta$-Curcumene & 1507 & 1514 & $0.02 \pm 0.03$ & & $0.06 \pm 0.07$ & $0.10 \pm 0.06$ & $0.03 \pm 0.04$ & $0.04 \pm 0.03$ \\
\hline$\gamma$-Cadinene & 1510 & 1513 & & & $0.02 \pm 0.04$ & $0.05 \pm 0.05$ & & \\
\hline Cubebol & 1513 & 1514 & & & & $0.18 \pm 0.31$ & $0.28 \pm 0.39$ & \\
\hline a-Cadinene & 1515 & 1537 & $0.28 \pm 0.12$ & $0.05 \pm 0.05$ & $0.28 \pm 0.48$ & $0.39 \pm 0.42$ & & \\
\hline Myristicin & 1519 & 1517 & $17.45 \pm 2.09$ & $10.52 \pm 2.95$ & $18.38 \pm 1.01$ & $19.93 \pm 1.13$ & $19.25 \pm 1.46$ & $18.47 \pm 0.91$ \\
\hline (E)- $\gamma$-Bisabolene & 1524 & 1529 & & & $0.05 \pm 0.05$ & $0.03 \pm 0.05$ & $0.03 \pm 0.04$ & $0.02 \pm 0.03$ \\
\hline trans-Cadina-1.4-diene & 1529 & 1533 & & & $0.04 \pm 0.04$ & $0.10 \pm 0.05$ & $0.03 \pm 0.04$ & $0.05 \pm 0.05$ \\
\hline a-Cadinene & 1535 & 1537 & & & & $0.02 \pm 0.03$ & & \\
\hline a-Copaen-11-ol & 1539 & 1539 & $0.03 \pm 0.05$ & & $0.14 \pm 0.14$ & $0.28 \pm 0.09$ & $0.16 \pm 0.11$ & $0.20 \pm 0.08$ \\
\hline Elemicin & 1545 & 1555 & $2.23 \pm 1.16$ & $0.28 \pm 0.36$ & $2.22 \pm 0.33$ & $3.13 \pm 0.43$ & $3.56 \pm 1.06$ & $3.92 \pm 0.75$ \\
\hline (E)-Nerolidol & 1559 & 1561 & $0.06 \pm 0.06$ & & $0.13 \pm 0.11$ & $0.35 \pm 0.22$ & $0.17 \pm 0.24$ & $0.27 \pm 0.10$ \\
\hline Spathulenol & 1573 & 1577 & & & & $0.08 \pm 0.09$ & & \\
\hline Germacrene D-4-ol & 1574 & 1574 & & & & & $0.05 \pm 0.07$ & \\
\hline Caryophyllene oxide & 1575 & 1582 & $0.02 \pm 0.03$ & & $0.06 \pm 0.05$ & $0.19 \pm 0.12$ & $0.08 \pm 0.01$ & $0.07 \pm 0.02$ \\
\hline 6-Methoxyelemicin & 1579 & 1595 & $0.02 \pm 0.03$ & & & $0.21 \pm 0.14$ & $0.18 \pm 0.25$ & $0.35 \pm 0.18$ \\
\hline Viridiflorol & 1592 & 1592 & & & & $0.06 \pm 0.10$ & & \\
\hline Humulene epoxide II & 1607 & 1608 & & & & $0.02 \pm 0.03$ & & \\
\hline Dillapiole & 1618 & 1620 & $71.65 \pm 7.30$ & $84.65 \pm 2.66$ & $61.12 \pm 6.71$ & $54.15 \pm 6.56$ & $54.27 \pm 5.32$ & $51.96 \pm 5.88$ \\
\hline 1-epi-Cubenol & 1627 & 1627 & & & $0.13 \pm 0.12$ & & & \\
\hline Muurola-4,10(14)-dien-1- $\beta$-ol & 1636 & 1630 & & & & $0.15 \pm 0.25$ & & \\
\hline a-epi-Muurolol & 1649 & 1640 & & & & $0.08 \pm 0.09$ & & \\
\hline a-Cadinol & 1660 & 1652 & & & $0.01 \pm 0.02$ & $0.06 \pm 0.07$ & & $0.02 \pm 0.03$ \\
\hline Apiole & 1670 & 1677 & $0.64 \pm 0.40$ & $0.06 \pm 0.11$ & $0.85 \pm 0.37$ & $1.72 \pm 0.68$ & $1.59 \pm 0.78$ & $1.78 \pm 0.37$ \\
\hline Monoterpene hydrocarbons & & & $0.74 \pm 0.84$ & $0.09 \pm 0.16$ & $2.35 \pm 2.78$ & $5.84 \pm 1.70$ & $6.45 \pm 2.13$ & $5.70 \pm 3.34$ \\
\hline Oxygenated monoterpenes & & & $0.63 \pm 0.54$ & $0.10 \pm 0.10$ & $0.75 \pm 1.09$ & $2.27 \pm 1.17$ & $2.11 \pm 2.77$ & $0.93 \pm 3.34$ \\
\hline Sesquiterpene hydrocarbons & & & $5.84 \pm 3.18$ & $1.63 \pm 0.84$ & $12.67 \pm 5.73$ & $10.35 \pm 5.79$ & $9.05 \pm 2.51$ & $10.41 \pm 2.82$ \\
\hline Oxygenated sesquiterpenes & & & $0.13 \pm 0.17$ & & $0.52 \pm 0.48$ & $1.56 \pm 1.51$ & $0.77 \pm 0.86$ & $0.63 \pm 0.24$ \\
\hline Phenylpropanoids & & & $92.04 \pm 11.02$ & $95.51 \pm 6.08$ & $82.63 \pm 8.47$ & $79.24 \pm 9.06$ & $78.92 \pm 8.88$ & $76.70 \pm 8.24$ \\
\hline Others & & & $0.21 \pm 0.09$ & $2.58 \pm 1.30$ & $0.41 \pm 0.07$ & $0.33 \pm 0.20$ & $0.22 \pm 0.06$ & $0.41 \pm 0.10$ \\
\hline Total & & & $99.59 \pm 15.84$ & $99.91 \pm 8.48$ & $99.33 \pm 18.62$ & $99.59 \pm 19.43$ & $97.52 \pm 17.21$ & $94.78 \pm 18.08$ \\
\hline
\end{tabular}

dpi: Days post inoculation; Control: P. aduncum non-inoculated with AMF; AMF: P. aduncum inoculated with AMF; Rlcal: Retention index calculated; Rllit: Retention Index of Library

* Statistical difference according to Bonferroni test $(p<0.05)$

a Microsoftean \pm standard deviation $(n=3)$

through the inoculation by AMF in the roots. The results showed dillapiole production decreased in roots and leaves. However, several monoterpenes and sesquiterpenes increased in the leaves, and 15 components were produced in the roots of inoculated plants. These results indicate a metabolic activity was induced by the inoculation of AMF and can serve to contribute to future studies on plant-fungal interactions. 

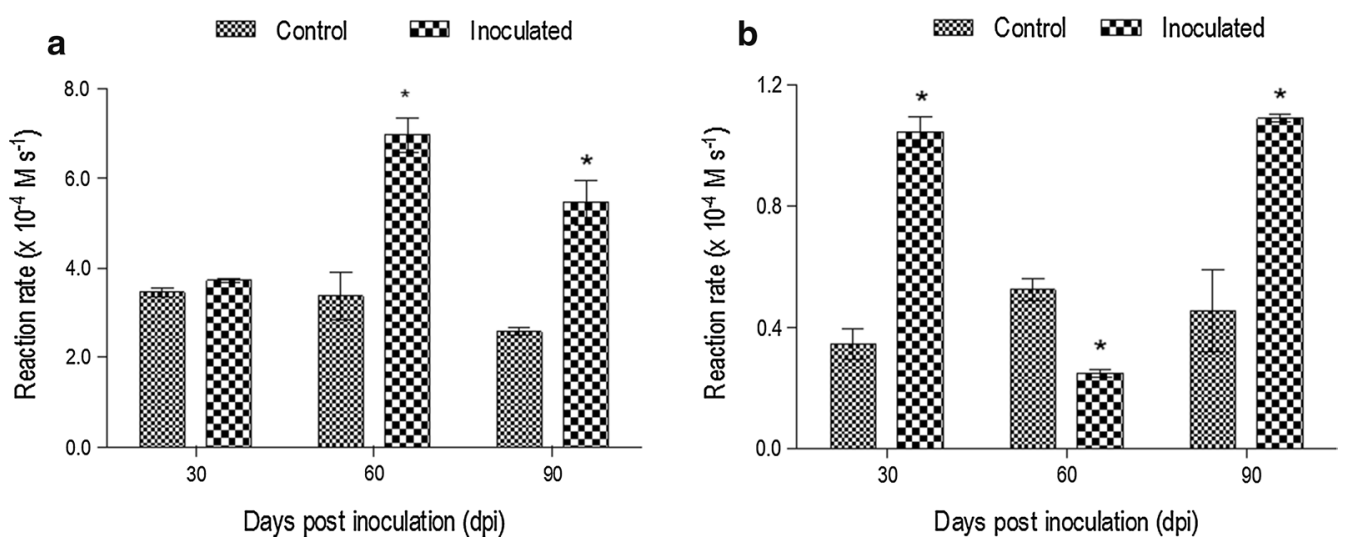

Fig. 3 Variation of LOX activity in inoculated and non-inoculated plants of P. aduncum. a Leaves; b Roots. *Statistical difference according to Bonferroni test $(p<0.05)$

\section{Authors' contributions}

JKRS and ARR participated in study designed; JSFO and LP .conducted the experiments; ALFAL assisted the experiments of plant anatomy; EAA performed the GC-MS analyzes, AMH provided and identified the AMFs species; JSFO, ARR and JKRS wrote the manuscript; JGSM, WNS and JKRS edited and revised the manuscript. All authors read and approved the final manuscript.

\section{Author details}

${ }^{1}$ Programa de Pós-Graduação em Biotecnologia, Universidade Federal do Pará, Belém, Pará, Brazil. ${ }^{2}$ Coordenação de Botânica, Museu Paraense Emílio Goeldi, Belém, Pará, Brazil. ${ }^{3}$ Programa de Pós-Graduação em Recursos Naturais da Amazônia, Universidade Federal do Oeste do Pará, Santarém, Pará, Brazil. ${ }^{4}$ Instituto de Estudo do Desenvolvimento Agrário e Regional, Universidade Federal do Sul e Sudeste do Pará, Marabá, Pará, Brazil. ${ }^{5}$ Department of Chemistry, University of Alabama in Huntsville, Huntsville, AL 35899, USA. ${ }^{6}$ Instituto de Estudos em Saúde e Biológicas, Universidade Federal do Sul e Sudeste do Pará, Marabá, Pará, Brazil.

\section{Acknowledgements}

The authors are grateful to the Coordenação de Aperfeiçoamento de Pessoal de Nível Superior (CAPES - Coordination for the Improvement of Higher Education Personnel) for providing a Master scholarship to J.S.F. De Oliveira (Grant Number 1550848).

\section{Competing interests}

The authors declare that they have no competing interests.

\section{Availability of data and materials}

All necessary data supporting our finding can be found within the article.

\section{Consent for publication}

All the authors agreed to publish in the journal.

\section{Ethics approval and consent to participate}

The manuscript is an original research and has not been published in others journals.

\section{Funding}

Not applicable.

\section{Publisher's Note}

Springer Nature remains neutral with regard to jurisdictional claims in published maps and institutional affiliations.

Received: 10 February 2019 Accepted: 16 February 2019 Published online: 26 February 2019

\section{References}

Adams RP (2007) Identification of essential oil components by gas chromatography/mass spectrometry, 4th edn. Allured Publishing Corporation, Carol Stream

Al-karaki G, McMichael B, Zak J (2004) Field response of wheat to arbuscular mycorrhizal fungi and drought stress. Mycorrhiza 14:263-269. https://doi. org/10.1007/s00572-003-0265-2

Almeida RP, Souto RNP, Silva MHL, Maia JGS (2009) Chemical variation in Piper aduncum and biological properties of its dillapiole-rich essential oil. Chem Biodiversity. 9:1427-1434. https://doi.org/10.1002/cbdv.200800212

Bárzan G, Aroca R, Paz JA, Chaumont F, Martinez-Ballesta MC, Carvajal M, RuizLozano JM (2012) Arbuscular mycorrhizal symbiosis increases relative apoplastic water flow in roots of the host plant under both well-watered and drought stress conditions. Ann Bot 109:1009-1017. https://doi. org/10.1093/aob/mcs007

Baysal T, Demirdoven A (2007) Lipoxygenase in fruits and vegetables: a review. Enzyme Microbl Technol. 40:491-496. https://doi.org/10.1016/j.enzmi ctec.2006.11.025

Bernard CB, Krishnamurty HG, Durst DCT, Philogene BJR, Sanchez-Vindas P, Hasbun C, Poveda L, San Roman L, Arnason JT (1995) Insecticidal defenses of Piperaceae from the Neotropics. J Chem Ecol 21:801-814

Bonfante P, Genre A (2010) Mechanisms underlying beneficial plant-fungus interactions in mycorrhizal symbiosis. Nat Commun 1:1-11. https://doi. org/10.1038/ncomms1046

Carlsen SCK, Understrup A, Fomsgaard IS, Mortensen AG, Ravnskov S (2008) Flavonoids in roots of white clover: interactions of arbuscular mycorrhizal fungi and a pathogenic fungus. Plant Soil 302:33-43. https://doi. org/10.1007/s11104-007-9452-9

Da Luz SFM, Reis LA, Lemos OF, Maia JGS, De Mello AH, Ramos AR, Da Silva JKR (2016) Effect of arbuscular mycorrhizal fungi on the essential oil composition and antioxidant activity of black pepper (Piper nigrum L.). Int J Appl Res Nat Prod 9:10-17. http://www.ijarnp.org/index.php/ijarnp/article/ view/355/pdf

Freitas MS, Martins MA, Vieira IJC (2004) Yield and quality of essential oils of Mentha arvensis in response to inoculation with arbuscular mycorrhizal fungi. Pesq Agropec Bras 39:887-894. https://doi.org/10.1590/S0100 $-204 \times 2004000900008$

Frosi G, Barros VA, Oliveira MT, Cavalcante UMT, Maia LC, Santos MG (2016) Increase in biomass of two woody species from a seasonal dry tropical forest in association with AMF with different phosphorus levels. Appl Soil Ecol 102:46-52. https://doi.org/10.1016/j.apsoil.2016.02.009

Gerlach G (1969) Botanische Mikrotechnik. Georg Thieme Verlag, Stuttgart, p 298

Gianinazzi-Pearson V, Brechenmacher $L$ (2004) Functional genomics of arbuscular mycorrhiza: decoding the symbiotic cell programme. Can J Bot 82:1228-1234. https://doi.org/10.1139/b04-096 
Godard K, White R, Bohlmann J (2008) Monoterpene-induced molecular responses in Arabidopsis thaliana. Phytochemistry 69:1838-1849. https:// doi.org/10.1016/j.phytochem.2008.02.011

Gouinguené SP, Turlings TCJ (2002) The effects of abiotic factors on induced volatile emissions in corn plants. Plant Physiol 129:1296-1307. https://doi. org/10.1104/pp.001941

Guerrini A, Sacchetti G, Rossi D, Paganetto G, Muzzoli M, Andreotti E, Tognolini M, Maldonado ME, Bruni R (2009) Bioactivities of Piper aduncum L. and Piper obliquum Ruiz \& Pavon (Piperaceae) essential oils from Eastern Ecuador. Environ Toxicol Pharmacol 27:39-48. https://doi.org/10.1016/j. etap.2008.08.002

Gutjahr C, Siegler H, Haga K, lino M, Paszkowski U (2015) Full establishment of arbuscular mycorrhizal symbiosis in rice occurs independently of enzymatic jasmonate biosynthesis. PLoS ONE 10:1-9. https://doi.org/10.1371/ journal.pone.0123422

Hartemink AE (2001) Biomass and nutrient accumulation of Piper aduncum and Imperata cylindrica fallows in the humid lowlands of Papua New Guinea. For Ecol Manag. 144:19-32. https://doi.org/10.1016/S0378 $-1127(00) 00655-1$

INVAM. International Culture Collection of Arbuscular and Vesicular-Arbuscular Mycorrhizal Fungi. 1992. http://invam.caf.wvu.edu/. Accessed 2 Mar 2018

Johansen DA (1940) Plant microtechnique. Mc Graw-Hill, New York, p 523

Karnovsky MJA (1965) Formaldehyde-glutaraldehyde fixative of high osmolality for use in electron microscopy. J Cell Biol 27:137-138. http://www.jstor .org/stable/1604673

Kiriachek SG, Azevedo LCB, Peres LEP, Lambais MR (2009) Regulação do desenvolvimento de micorrizas arbusculares. R Bras Ci Solo 33:1-16. https://doi. org/10.1590/S0100-06832009000100001

Kloucek P, Polesny Z, Svobodova B, Vlkova E, Kokoska L (2005) Antibacterial screening of some Peruvian medicinal plants used in Callería District. J Ethno Pharmacol 99:309-312. https://doi.org/10.1016/j.jep.2005.01.062

Kraus JE, Arduin M (1997) Manual básico de métodos em morfologia vegetal. 198p. EDUR

Liavonchanka A, Feussner I (2006) Lipoxygenases: occurrence, functions and catalysis. J Plant Physiol 163:348-357. https://doi.org/10.1016/j.jplph .2005 .11 .006

Maia JGS, Zohhbi MGB, Andrade EHA, Santos AS, Da Silva MHL, Luz AIR, Bastos CN (1998) Constituents of the essential oil of Piper aduncum L. growing wild in the Amazon region. Flavour Fragr J 13:269-272. https ://doi.org/10.1002/(SICI)1099-1026(1998070)13:4\%3c269:AID-FFJ74 4\%3e3.0.CO;2-A

Meireles EM, Xavier LP, Ramos AR, Maia JGS, Setzer WN, Da Silva JKR (2016) Phenylpropanoids produced by Piper divaricatum, a resistant species to infection by Fusarium solani f. sp. piperis, the pathogenic agent of Fusariosis in Black Pepper. J Plant Pathol Microbiol 7:1-6. https://doi. org/10.4172/2157-7471.1000333

Misni N, Othman H, Sulaiman S (2011) The effect of Piper aduncum Linn. (Family:Piperaceae) essential oil as aerosol spray against Aedes aegypti (L.) and Aedes albopictus Skuse. Trop Biomed 28:249-258

Mora-Romero GA, Cervantes-Gámez RG, Galindo-Flores H, Gonzales-Ortiz MA, Felix-Gastélum R, Maldonado-Mendonza IE, Salinas Perez R, León-Félix J, Martpinez-Valenzuela MC, López-Meyer M (2015) Mycorrhiza-induced protection against pathogens is both genotype-specific and graft-transmissible. Symbiosis 66:55-64. https://doi.org/10.1007/s13199-015-0334-2

Morcillo RJL, Ocampo JA, Garrido JMG (2012) Plant 9-lox oxylipin metabolism in response to arbuscular mycorrhiza. Plant Signal Behav. 7:1584-1588. https://doi.org/10.4161/psb.22098

Muthukumar T, Tamilselvi V (2010) Occurrence and morphology of endorhizal fungi in crop species. Trop Subtrop Agroecosyst 12:593-604. http://www. revista.ccba.uady.mx/ojs/index.php/TSA/article/view/599

Nell M, Wawrosch C, Steinkellner S, Vierheilig H, Kopp B, Lössl A, Franz C, Novak J, Zitterl-Eglseer K (2010) Root colonization by symbiotic arbuscular mycorrhizal fungi increases sesquiterpenic acid concentrations in Valeriana officinalis L. Planta Med 76:393-398. https://doi. org/10.1055/s-0029-1186180

Neumann E, Schmid B, Römheld V, George E (2009) Extraradical development and contribution to plant performance of an arbuscular mycorrhizal symbiosis exposed to complete or partial roots one drying. Mycorrhiza 20:13-23. https://doi.org/10.1007/s00572-009-0259-9

NIST (2011) National institute of standard and technology (2011) NIST standard reference database number 69. http://webbook.nist.gov/. Accessed 25 Nov 2018

Oehl F, Sieverding E, Palenzuela J, Ineichen K, Silva GAS (2011) Advances in Glomeromycota taxonomy and classification. IMA Fungus 2:191-199. https://doi.org/10.5598/imafungus.2011.02.02.10

Quaglia M, Fabrizi M, Zazzerini A, Zadra C (2012) Role of pathogen-induced volatiles in the Nicotiana tabacume, Golovinomyces cichoracearum interaction. Plant Physiol Biochem 52:9-20. https://doi.org/10.1016/j.plaph y.2011.11.006

Requena N, Mann P, Hampp R, Franken P (2002) Early developmentally regulated genes in the arbuscular mycorrhizal fungus Glomus mosseae: GmG1N1, a novel gene encoding a protein with homology to the C-terminus of metazoan hedgehog proteins. Plant Soil 244:129-139. http://www.iab.kit.edu/heisenberg/download/2002_Requena.pdf

Russomanno OMR, Kruppa PC, Minhoni MTA (2008) Influência de fungos micorrízicos arbusculares no desenvolvimento de plantas de alecrim e manjericão. Arq Inst Biol 75:37-43. http://www.biologico.sp.gov.br/uploa ds/docs/arq/v75_1/russomanno.pdf

Seema HS, Garampalli RH (2015) Effect of arbuscular mycorrhizal fungi on growth and biomass enhancement in Piper longum L. (Piperaceae). Int J Curr Microbiol Appl Sci 5:11-18. https://www.jjcmas.com/vol-4-1/H.\%20 S.\%20Seema\%20and\%20Rajkumar\%20H.\%20Garampalli.pdf

Silva HSA, Romeiro RS, Macagnan D, Vieira BAH, Pereira MCB, Mounteer A (2004) Rhizobacterial induction of systemic resistance in tomato plants: non-specific protection and increase in enzyme activities. Biol Control 29:288-295. https://doi.org/10.1016/S1049-9644(03)00163-4

Smith SE, Read DJ (2008) Mycorrhizal symbiosis, 3rd edn. Academic Press, London, p 800

Smith FA, Smith SE (1997) Structural diversity in (vesicular)-arbuscular mycorrhizal symbioses. New Phytol 137:373-388. https://doi.org/10.104 6/j.1469-8137.1997.00848.x

Sousa PJC, Barros CAL, Rocha JCS, Lira DS, Monteiro GM, Maia JGS (2008) Avaliação toxicológica do óleo essencial de Piper aduncum L. Rev bras farmacogn 18:217-221. https://doi.org/10.1590/S0102-695X2008000200013

Souto RNP, Harada AY, Andrade EHA, Maia JGS (2012) Insecticidal activity of Piper essential oils from the Amazon against the fire ant Solenopsis saevissima (Smith) (Hymenoptera: Formicidae). Neotrop Entomol. 41:510-517. https://doi.org/10.1007/s13744-012-0080-6

Tanaka A, Fujita K (1979) Growth, photosynthesis and yield components in relation to grain yield of the field bean. J Fac Agric Hokkaido Univ 5:145-238. https://eprints.lib.hokudai.ac.jp/dspace/handle/2115/12922

The Plant List (2013) Version 1.1. http://www.theplantlist.org/. Accessed 02 Mar 2018

Van Den Dool H, Kratz PDA (1966) A Generalization of the retention index system including linear temperature programmed gas-liquid partition chromatography. J Chromatogr A 11:463-466. https://doi.org/10.1016/ S0021-9673(01)80947-X

Xie X, Weng B, Cai B, Dong Y, Yan C (2014) Effects of arbuscular mycorrhizal inoculation and phosphorus supplyon the growth and nutrient uptake of Kandelia obovata (Sheue: liu \& Yong) seedlings in autoclaved soil. Appl Soil Ecol 75:162-171. https://doi.org/10.1016/j.apsoil.2013.11.009

Yuncker TG (1972) The Piperaceae of Brazil. Hoehnea. 2:19-366. http://www. scielo.br/scielo.php?script $=$ sci_nlinks\&ref $=000101 \&$ pid $=$ S2236-89062 $00900030000400021 \& \operatorname{lng}=e n$ 